\title{
Global Impact Of Tax Considerations For Displaced Workers
}

Larry R. Garrison, University of Missouri-Kansas City, USA

Richard Cummings, University of Wisconsin-Whitewater, USA

\begin{abstract}
The current recession, combined with the globalization of the economy, outsourcing of jobs, and business downsizing, has resulted in thousands of workers experiencing the loss of their job. In addition to other circumstances that arise through the loss of a job, a new and unfamiliar set of tax issues can result through this new situation. This article will address some of the tax issues affecting displaced workers. The discussion will include strategies for displaced worker's income, deductions, tax credits and special considerations.
\end{abstract}

Keywords: Tax Strategy, Displaced Worker, Severance Pay, Unemployment Income, Public Assistance Payments, Earned Income Credit, American Opportunity Tax Credit

\section{INTRODUCTION}

hen businesses around the world lay off employees due to an economic recession, globalization of the economy, or outsourcing of jobs, the unemployed taxpayer finds himself in a new environment. This new environment can be much more manageable if the taxpayer has a strategy to take advantage of current tax law and policy. This article will provide a road map for the newly displaced worker as they navigate their income, deductions, tax credits, and special considerations toward an effective tax strategy.

\section{INCOME}

\section{Severance Pay}

Terminated employees may receive various types of payments from their employer. One type of payment is severance pay, which can result from voluntary termination by the employee through disability or illness, or from an involuntary termination by some action of the employer, such as downsizing, sale, or closure of the business operation. Severance pay is taxable as compensation income. ${ }^{1}$ A lump-sum payment for the cancellation of an employment contract is also taxable income and included in the year the lump-sum payment is received. Any other payments made, such as a bonus-type payment for number of years of service, are includible in taxable income. ${ }^{2}$

\section{Golden Parachute Payments}

A displaced worker may receive severance pay in the form of golden parachute payments. Golden parachute payments are those made to an employee as a result of a change in ownership of a corporation. These payments are considered excess severance pay and therefore, taxable income. For the employee, a 20 percent excise tax is also assessed and withheld on the excess golden parachute payments. ${ }^{3}$

For the employer, a deduction is denied for payments in the nature of compensation if:

1. The payment is contingent on a change in ownership or effective control of the corporation or in the ownership of a substantial portion of the assets of the corporation, and

2. The aggregate present value of the payments in the nature of compensation, which is contingent on the change, equals or exceeds the amount equal to three time the base amount. ${ }^{4}$ 
Golden parachute payments do not include payments from most qualified plans, including those described in Section 401(a), which includes a tax-exempt trust under Section 501(a), a Section 403(a) annuity plan, a Section 408(k) simplified employee pension plan, and a Section 408(p) simple retirement account. ${ }^{5}$

\section{Unemployment Benefits}

Unemployment benefits paid through a program sponsored by a state or Federal government are taxable income. ${ }^{6}$ The American Recovery and Reinvestment Act of 2009 excluded the first $\$ 2,400$ of unemployment benefits from taxable income in $2009 .^{7}$

Unemployment benefits are also taxable if the employee helped to fund the unemployment benefits program through the payment of deductible union dues. ${ }^{8}$ In the case of nondeductible contributions paid by the employee, only unemployment benefits in excess of the amount funded through the nondeductible contributions by the employee are includible in income. ${ }^{9}$

Supplemental unemployment benefits received from an employer-financed fund are not considered unemployment benefits, but are taxable wages. Employer-financed funds do not receive contributions from employees. ${ }^{10}$

Recipients of unemployment benefits can voluntarily have a flat 10 percent tax withheld from their benefits by filing a Form W-4V, Voluntary Withholding Request. ${ }^{11}$

\section{Accrued Vacation Pay or Sick Leave}

Accrued vacation pay or accrued sick leave is includible in income as taxable compensation when paid on termination of a employee. ${ }^{12}$

\section{Public Assistance Payments}

For the first time in their lives, a terminated employee may qualify for public assistance payments, which, along with food stamps, are not included in income. ${ }^{13}$

\section{Gifts from Family or Friends}

As additional financial assistance, gifts may be received from family or friends. These gifts are not taxable for income tax purposes. ${ }^{14}$ Any income, such as interest or dividend income earned on the gifted property after the gift is received by the done, is taxable to the donee. Any cash or property received by the employee from their employer cannot be excluded as a gift. ${ }^{15}$

Gifts taxes may be owed by the family member or friend on the gift, if the gift amount exceeds a specified maximum amount. ${ }^{16}$

\section{Sale of Assets}

For additional cash, the displaced worker may need to sell some of their assets. The sale of investment assets, such as stocks and bonds, results in taxable income. Any gains or losses on the sales may receive capital gains treatment and a lower tax rate if the capital assets have been held longer than one year. ${ }^{17}$

\section{Sale of Personal Residence}

A taxpayer who experiences a loss of their job may need to sell their personal residence. If the sale of a personal residence results in a gain, Section 121 provides for the exclusion of up to $\$ 250,000$ of the realized gain on the sale. The exclusion is increased to $\$ 500,000$ for married couples filing a joint tax return. To qualify for the exclusion, the residence must have been owned and used by the taxpayer as their principal residence for at least two 
years during the five-year period ending on the date of sale. ${ }^{18}$ Since a personal residence is considered a personal use asset, any loss on the sale of a personal residence is nondeductible. ${ }^{19}$

The Section 121 exclusion does not apply to any sales occurring within two years of its last use. ${ }^{20}$ However, an exception to the two-year ownership rule and the two-year rule for use of the Section 121 exclusion is available in certain circumstances. These two-year rules are waived for a change in place of employment, which must occur during the period of the taxpayer's ownership and use of the property as the taxpayer's principal residence. Also, the change of place of employment must satisfy the distance safe harbor test, which requires that the location of the taxpayer's new place of employment is at least 50 miles further from the residence sold or exchanged than was the former place of employment. If this exception is used, only a partial exclusion is allowed. Change of employment includes commencement of employment with a new employer, the continuation of employment with the same employer, or continuation of self-employment. ${ }^{21}$

Another exception to the two-year rule is for unforeseen circumstances. One of the unforeseen circumstances is cession of employment that results in eligibility for unemployment compensation. Another unforeseen circumstance is the change of employment or self-employment that results in the taxpayer being unable to pay housing costs and reasonable basic living expenses for the taxpayer's household. If this exception is used, only a partial exclusion is allowed. ${ }^{22}$

To compute the partial exclusion, the Section 121 exclusion amount of $\$ 250,000$ or $\$ 500,000$, whichever is applicable, is multiplied by a fraction. The numerator of the fraction is the number of qualifying months and the denominator is 24 months. The result is the amount of the excluded gain. ${ }^{23}$

\section{Incentive Stock Options}

To generate needed cash, a terminated employee may need to exercise stock options granted by their employer, one which is an incentive stock option. Generally, the receipt or exercise of an incentive stock option (ISO) does not result in taxable income. Taxable income may result when the employee sells the ISO stock. However, if the taxpayer sells the ISO stock before the end of the holding period, then any gain is taxable with a portion of the gain possibly being ordinary income. To meet the holding period requirements, the employee must not dispose of the stock within two years after the option is granted or within one year after acquiring the stock. ${ }^{24}$

If the holding period requirements are not met, upon the sale of the stock, the difference between the option price and the value of the stock at the date the option was exercised is considered ordinary income. There is a shortterm or long-term capital gain for the difference between the amount realized for the stock and the value of the stock at the date the option was exercised, depending on the holding period of the stock sold.

An employer had no deduction for an ISO unless the ISO is disposed of before the end of the holding period. Then the employer has a deduction for an amount equal to the ordinary income the taxpayer included in income. exercise. $^{25}$

The taxpayer must be an employee from the date the option is granted until three months before the date of

\section{Retirement Plan Withdrawals}

Retirement plans may be a needed source of cash. However, there are specific rules and tax consequences for withdrawing cash from these plans. Generally, all pension plans, including qualified defined benefit plans, defined contribution plans, tradition Individual Retirement Accounts (IRA), annuities, unfunded deferred compensation plans of state and local governments and tax-exempt employers, and tax-sheltered custodial accounts and annuities have uniform minimum distribution requirements. Minimum distributions must begin by April 1 of the calendar year following the later of (1) the calendar year in which the employee attains age $701 / 2$ or (2) the calendar year in which the employee retires. For 5 percent owners or traditional IRA owners, minimum distributions must begin by April 1 of the calendar year following the year in which they reach 70 1/2. For Roth 
IRA holders, there is no minimum distribution requirement. Also, Roth IRA holders do not pay tax on qualified distributions from their Roth IRA. ${ }^{26}$

Generally, retirement plan withdrawals received by an employee before they attain their eligible retirement age, or rolled over into an IRA or another qualified retirement plan within 60 days, are subject to the Section 72 annuity taxation rules. Rollovers defer immediate taxation of the withdrawal and can be direct or indirect. A direct rollover occurs when the balance in the qualified employer retirement plan is transferred directly into another qualified employer retirement plan or IRA. An indirect rollover occurs when the balance in the qualified employer retirement plan is paid to the employee who has 60 days to transfer the balance into another qualified employer account or IRA. However, an indirect rollover has 20 percent withheld from the balance paid to the employee. Since 100 percent of the balance must be rolled over for the entire balance to be tax-deferred, the employee may be required to provide their own funds to bring the balance to be rolled over back to 100 percent. ${ }^{27}$

For taxpayers who have made nondeductible contributions to an IRA, Form 8606, Nondeductible IRAs, is used to compute the basis of an IRA, including a Roth IRA, for tax reporting purposes. ${ }^{28}$

If a taxpayer takes an early distribution from a qualified retirement plan, there is a 10 percent additional tax on the amount of the distribution included in gross income. ${ }^{29}$ This early distribution penalty does not apply to:

1. Distributions that are made on or after the date the employee attains age 59 1/2.

2. Distributions made to an employee after separation from service because of early retirement under the plan after attaining age 55. This exception does not apply to traditional IRAs.

Contributions to an IRA can be withdrawn without the 10 percent early distribution penalty being assessed if the contributions are withdrawn before the due date of the return. Any interest or dividends earned on the contribution also need to be withdrawn. No tax is due on the withdrawal if no deduction was taken for the contribution on a tax return and any interest or dividends earned on the contribution are included in income.

\section{Accident and Health Benefits}

A laid-off worker is considered an employee in regard to the tax provisions related to accident and health benefits under Sections 105 and 106 if the laid-off worker continues to receive accident and health benefits under a collective bargaining agreement. ${ }^{30}$ The same result applies for a laid-off worker who receives continuing coverage under a severance plan. ${ }^{31}$ Section 105 provides that amounts received by an employee through accident or health insurance for personal injuries or sickness are included in gross income to the extent that the amounts:

1. are attributable to contributions by the employer, which were not includible in the gross income of the employee, or

2. are paid by the employer.

Section 106 provides that the gross income of an employee does not include employer-provided coverage under an accident or health plan.

\section{DEDUCTIONS}

\section{Job Placement Assistance}

Some employers provide job placement assistance for terminated employees. Job placement assistance can be classified as a working condition fringe benefit if the employer receives a "substantial business benefit" from providing the job placement assistance. As a working condition fringe benefit, job placement assistance would be excludable from the employee's income if:

1. The employer receives a substantial business benefit from the provision of the property or services that is distinct from the benefit that it would derive from the mere payment of additional compensation, and 
2. The employee's hypothetical payment for the property and services would otherwise be allowable as a deduction by the employee under Section $162 .{ }^{32}$

A substantial business benefit would include promoting a positive corporate image, maintaining employee morale, avoiding wrongful termination suits, fostering a positive work atmosphere, and helping attract quality employees. ${ }^{33}$

If the job placement assistance does not qualify as an excludable working condition fringe, or if the taxpayer chooses to receive a reduced amount of severance pay so they can receive job placement assistance, the amount of the job placement assistance included in income may be deducted as an employee business expense in the miscellaneous itemized deduction section of Schedule A of Form 1040. The total of the miscellaneous itemized deductions is subject to a floor of two percent of the taxpayer's adjusted gross income. ${ }^{34}$

\section{Job Hunting Expenses}

A terminated employee can deduct expenses incurred for seeking a new job in the same trade or business. The expenses are deductible whether or not the taxpayer actually gets the new job. However, job hunting expenses are not deductible if the taxpayer is seeking their first job or is seeking a job in a new trade or business. There is a variety of expenses incurred while job hunting. Employment and outplacement agency fees are deductible if paid by the job seeker. Resume preparation costs, including typing, printing, and mailing, are deductible expenses. Travel expenses for job interviews may also be deductible if the travel is primarily looking for a new job and not primarily personal travel. Travel expenses incurred looking for a new job while in the area are deductible, even if the travel expenses to and from the area are nondeductible due to the primarily personal nature of the trip. ${ }^{35}$

Job hunting expenses are miscellaneous itemized deductions subject to the floor of two percent of the taxpayer's adjusted gross income. ${ }^{36}$

\section{Moving Expenses}

A terminated employee may incur moving expenses in relocating to a new job or starting their own business. Moving expenses are deductible for both terminated employees and self-employed taxpayers. Moving expenses are allowed if the taxpayer changes from the status of going from an employee to self-employed or vice versa. Moving expenses are also deductible if a taxpayer is unemployed before they find a job in the new area. To qualify the moving expenses for a deduction, two tests must be satisfied. ${ }^{37}$

The distance test requires that the taxpayer's new job location must be at least 50 miles farther from the taxpayer's former residence than their former residence was from the former place of employment. The time test requires a taxpayer to be employed on a full-time basis at the new location for 39 weeks within the 12 months following the move. For self-employed taxpayers, they must work at the new location for 78 weeks during the first two years at the new location. This time test is waived if the taxpayer is discharged or transferred by the new employer. $^{38}$

For reporting purposes, the taxpayer may take the moving expense deduction in the year the expenses are incurred, even if the 39-week test has not been satisfied. If the taxpayer later fails to meet the 39-week test, the taxpayer may either increase the income reported in the following year by the amount of the previously deducted moving expenses or the taxpayer may file an amended income tax return for the year of the move. A taxpayer may choose not to deduct the moving expenses in the year of the move and wait until the time test is met and then file an amended income tax return for the year of the move. ${ }^{39}$

Deductible moving expenses include the reasonable expenses of moving the taxpayer's household goods and personal effects and travel expenses from the former residence to the new residence. Travel expenses include travel expenses for the taxpayer and their family, but not any expenses incurred for meals for the taxpayer and their family. Actual automobile expenses, or the automatic mileage method, may be used for automobile expenses. If using actual expenses, depreciation is not included. The mileage rate for the automatic mileage method is 16.5 cents a mile (2010). ${ }^{40}$ 
Moving expenses that are not reimbursed, or if the taxpayer is self-employed, are reported on Form 3903, Moving Expenses. ${ }^{41}$

\section{TAX CREDITS}

\section{Earned Income Credit}

A job loss may result in a reduction of income that would qualify the taxpayer for the earned income credit. For earned income credit purposes, earned income generally includes employee compensation and net earnings from self-employment. Earned income does not include alimony, dividends, interest, nontaxable employee compensation, or pension income. The earned income credit is not available to taxpayer's with unearned income exceeding certain amounts. The number of qualifying children affects the credit percentage. The earned income credit is also available to low-income earning taxpayers without children. The earned income credit amount is computed by multiplying a maximum amount of earned income by a credit percentage. The Earned Income Credit Table is used to determine the appropriate amount of the credit. ${ }^{42}$

In 2010 , the maximum earned income credit for a taxpayer with one qualifying child is $\$ 3,050(\$ 8,970$ times the $34 \%$ credit percentage), $\$ 5,036$ for two qualifying children $(\$ 12,590$ times the $40 \%$ credit percentage), and $\$ 5,666$ ( $\$ 12,590$ times the $45 \%$ credit percentage) for a taxpayer with three or more qualifying children. There is a phase-out if the taxpayer's earned income or adjusted gross income exceeds certain thresholds. If the earned income or adjusted gross income exceeds $\$ 21,460$ (2010) for married taxpayers filing a joint tax return, or $\$ 16,450$ (2010) for all other taxpayers, the excess is multiplied by the appropriate phase-out percentage and then subtracted from the maximum earned income credit.

Taxpayers in the 25 to 64 age range, who are not claimed as a dependent on another taxpayer's return and have no children, can also claim a credit. The credit is computed using a maximum earned income of $\$ 5,980$ (2010) times 7.65 percent and reduced by 7.65 percent of the earned income greater than $\$ 12,490$ (2010) for married taxpayers filing a joint return or $\$ 7,480$ (2010) for all other taxpayers.

An advanced payment from the taxpayer's employer of the potential earned income credit is available. The advanced payment cannot exceed 60 percent of the credit available to a taxpayer with one qualifying child. Since this is an election, the taxpayer files a Form W-5, Earned Income Credit Advance Payment Certificate, with their employer. The taxpayer is required to file a tax return for the tax year that advance payment is received. ${ }^{43}$

\section{Education Credits}

A terminated taxpayer may need additional education or retraining to re-enter the job market. However, the general deduction for education expenses applies to employees. Since the discussion relates to terminated employees, the education expenses addressed under this heading will relate to education expenses, either deductible or subject to a tax credit by taxpayers who are not currently employed. Of course, self-employed taxpayers can deduct education expenses as ordinary and necessary business expenses if the education is related to their particular trade or business activity. ${ }^{44}$

A deduction for adjusted gross income is available for qualified tuition and related expenses involving postsecondary education expenses. The maximum amount of the deduction depends on the year the expense is incurred and the taxpayer's modified adjusted gross income. Education-related expenses include qualified tuition and related expenses, excluding student activity fees, books, and room and board. ${ }^{45}$

There are two tax credits that are applicable to out-of-work taxpayers. These two non-refundable credits are the American Opportunity Tax Credit (effective for 2009 and 2010)(a modification of the HOPE scholarship credit) and the lifetime learning credit. The credits apply to qualifying tuition and related expenses incurred in pursuing undergraduate or graduate degrees or vocational training. Eligible expenses do not include textbooks, room, or board. Both credits are subject to income limitations. ${ }^{46}$ 
The American Opportunity Tax Credit allows a maximum credit of $\$ 2,500$ a year (2010). The credit allows 100 percent of the first $\$ 2,000$ in tuition plus 25 percent of the expenses that exceed $\$ 2,000$, but do not exceed $\$ 4,000$ for the first four years of post-secondary education. Generally, 40 percent of the credit is refundable for most taxpayers. Gross income thresholds may reduce the amount of the available credit. ${ }^{47}$

The lifetime learning credit allows a maximum credit of $\$ 2,000$ a year (2010). The credit allows a 20 percent credit applicable, up to $\$ 10,000$ per year in tuition expenses. Either the American Opportunity Tax Credit or the HOPE credit and the lifetime learning credit cannot be taken in the same year for the same student. The lifetime learning credit is available for all years of post-secondary education and is available for an unlimited number of years. Therefore, the lifetime learning credit is available to those taxpayers who are seeking new skills or maintaining their present skills. ${ }^{48}$

\section{Health Coverage Tax Credit (HCTC)}

Workers who have lost their jobs because of increased imports or a shift in production to another country may be eligible for a Health Coverage Tax Credit (HCTC). These former employees are classified as an eligible Trade Adjustment Assistance (TAA), Alternative Trade Adjustment Assistance (ATAA), or Pension Benefit Guaranty Corporation (PBGC) recipient. The refundable credit is equal to 80 percent of the amount paid by the taxpayer for coverage of the taxpayer and qualifying family members for COBRA (Consolidated Omnibus Budget Reconciliation Act) continuation health insurance premiums for eligible coverage months. The refundable credit was increased from 65 percent to 80 percent for eligible coverage months beginning after April 30, 2009 and before January 1, 2011. The remaining 20 percent of the health insurance premiums are paid by the former employee. After the taxpayer has registered for the program, the employer pays 20 percent of their premium and the Federal government contributes the remaining 80 percent. There are specific criteria for receiving the HCTC. Form 8885, Health Coverage Tax Credit, and the related instructions should be referred to in determining eligibility. ${ }^{49}$

\section{SPECIAL CONSIDERATIONS}

\section{Self-Employment Tax}

A terminated employee may decide to start their own business. A survey commissioned by Careerbuilders.com reported that 23 percent of laid-off mature workers were considering starting their own business. ${ }^{50}$ If the business is unincorporated, the income may be classified as self-employment income and therefore subject to self-employment tax. Net earnings from self-employment include (1) gross income from a trade or business, minus any allowable trade or business deductions, (2) distributive share of partnership income or loss from a trade or business, and (3) net income from providing personal services as an independent contractor.

Self-employed taxpayers pay a tax on self-employment income to provide for Social Security and Medicare benefits. Self-employment tax is applied to net earnings of $\$ 400$ or more from self-employment. The total selfemployment tax rate is 15.3 percent (2010). The Social Security percentage is 12.4 percent for self-employment income up to $\$ 106,800$ and the Medicare percentage is 2.9 percent for all self-employment income with no maximum for $2010 .^{51}$

The computation of the self-employment tax is somewhat complicated as self-employed taxpayers are allowed a deduction from net earnings from self-employment for one-half of the self-employment rate in determining their self-employment tax. They also have an income tax deduction for one-half of the selfemployment taxes paid. This income tax deduction is for adjusted gross income. ${ }^{52}$

\section{Estimated Tax Payments}

Former salaried or hourly employees may not be familiar with the payment of estimated income taxes as their tax obligations might have been taken care of through withholding. If they become a self-employed taxpayer, then they may be required to pay estimated taxes. 
Estimated taxes are basically the amount of taxes owed, including Federal income tax, alternative minimum tax, and self-employment tax, minus any amounts withheld or tax credits. Taxpayers who have estimated taxes of $\$ 1,000$ or more for the year and whose withholding does not equal or exceed the required annual payment, must make quarterly estimated tax payments. ${ }^{53}$ If estimated taxes are underpaid, there may be an underpayment penalty assessed. However, there is no penalty if the taxpayer had no tax liability for the preceding 12-month taxable year and the taxpayer was a U.S. citizen or resident for the entire preceding tax year. There is also no penalty applied if the income tax withheld and the other tax credits are at least 100 percent (or 110\% for higher income taxpayers) of the tax shown on the previous year's return. Form 1040-ES, Estimated Tax for Individuals, is sent to the IRS along with the appropriate estimated tax payment for the quarter. Electronic payments are also available. ${ }^{54}$

The required annual estimated tax is the smaller of (1) 90 percent of the tax shown on the current year's return or (2) 100 percent of the tax shown on the preceding year's return. The percent increases to 110 percent if the adjusted gross income on the preceding year's return is in excess of $\$ 150,000(\$ 75,000$ for married filing separate taxpayers). If an estimated tax payment is due, then a quarter of the annual payment is due on April 15, June 15, and September 15 of the tax year and January 15 of the following year. ${ }^{55}$

A non-deductible underpayment penalty is applied on the amount of the underpayment. The penalty rate applied is adjusted on a quarterly basis for changes in the average prime rate. An underpayment arises when any estimated installment payment is less than 25 percent of the required annual payment. The estimated installment payment is the total of the estimated tax paid plus any income tax withheld. Form 2210, Underpayment of Estimated Taxes by Individuals, Estates, and Trusts, is used to compute the penalty or to show that no penalty is applicable. ${ }^{56}$

\section{Installment Payments}

The IRS has developed an installment payment procedure for taxpayers who may not be able to pay the full amount of tax they owe when they file their federal income tax return. Taxpayer use Form 9465, Installment Agreement Request, to make the request. The request for an installment payment plan is generally automatic if all of the following requirements are met:

1. During the past five years, the taxpayer (and spouse if filing a joint return) has timely filed all income tax returns and paid any income tax due, and has not entered into an installment agreement for payment of income tax.

2. The IRS determines that the taxpayer cannot pay the tax owed in full when the tax is due and the taxpayer has given the IRS the information they need to make that determination.

3. The taxpayer agrees to pay the full amount owed within three years and to comply with the tax laws while the agreement is in effect.

Taxpayers are charged a fee of $\$ 105$, or $\$ 52$ if the payment is made by electronic funds withdrawal. The fee is not included with the request, but is billed later. The taxpayer generally receives their approval or denial letter from the IRS within 30 days after Form 9465 is received by the IRS. The letter will explain the monthly payment procedure and amount. After each payment is received, the taxpayer will receive a letter showing the next payment amount and due date. Taxpayers using an automatic payments through electronic transfers will not receive a letter. All future tax liabilities must be kept current. All previously required federal income tax returns must have been filed to receive approval for the installment payment request. Also, any federal income tax refunds received in the future will be applied against the installment debt.

Taxpayers must be reminded not to default on the agreement. The IRS can take enforcement actions, including filing a Notice of Federal Lien or Levy to collect the entire amount owed. Therefore, electronic payment transfers are recommended to avoid a default situation. ${ }^{57}$ 


\section{TAXPAYER ADVOCATE SERVICE}

The Taxpayer Advocate Service (TAS) is an independent organization within the IRS. ${ }^{58}$ The TAS assists taxpayers who believe they are suffering or are about to suffer a significant hardship as a result of actions by the IRS. Significant hardship includes, but is not limited to:

1. An immediate threat of adverse action;

2. A delay of more than 30 days in resolving taxpayer account problems;

3. The incurring by the taxpayer of significant costs, including fees for professional representation if relief is not granted; or

4. Irreparable injury to, or a long-term adverse impact on, the taxpayer if relief is not granted. ${ }^{59}$

Form 911, Request for Taxpayer Advocate Service Assistance (and Application for Taxpayer Assistance Order), is filed if the IRS will not grant the assistance requested by the taxpayer or if the IRS will not grant the assistance in a timely manner. Form 911 lists several additional "hardship" situations that are not included in the four listed above from Section 7811. On receipt of Form 911, the TAS will generally request that the IRS activities in question be ceased while the Form 911 is being reviewed.

\section{CONCLUSION}

The loss of a job through downsizing or globalization may create tax situations that are unfamiliar to a taxpayer. This article addressed selected tax issues involving income, deductions, tax credits, and other tax issues that may arise due to loss of employment. Taxpayers and practitioners need to be aware of the various tax rules and regulations related to the situations that may result from the loss of a job.

\section{AUTHOR INFORMATION}

Larry R. Garrison, Ph.D., CPA, is a Professor of Accountancy at the Henry W. Bloch School of Business and Public Administration at the University of Missouri-Kansas City. Dr. Garrison teaches undergraduate and graduate tax courses covering taxation of business entities and tax research. Dr. Garrison research interests include federal and state taxation of individuals and entities.

Richard G. Cummings, Ph.D., CPA, is an Associate Professor of Accounting at the University of WisconsinWhitewater. Dr. Cummings teaches individual taxation and MBA- Financial Accounting. His research interests include: empirical studies in horizontal equity in individual taxation, the effect of Subchapter $\mathrm{S}$ election in community banks, international accounting, and accounting education.

\section{ENDNOTES}

${ }^{1}$ IRS Publication 525, Taxable and Nontaxable Income, 2009, pg. 4.

${ }^{2}$ PLR 199928013 (April 12, 1999).

${ }^{3}$ Sec. 4999(a).

${ }_{5}^{4}$ Sec. $280 \mathrm{G}$.

${ }^{5}$ Sec. $280 \mathrm{G}(\mathrm{b})(6)$. Also Treas. Regs. Sec. 1.280G-1

${ }^{6}$ Sec. 85.

${ }^{7}$ American Recovery and Reinvestment Act of 2009, P. L. 111-5 (February 17, 2009).

${ }^{8}$ IRS Publication 525, Taxable and Nontaxable Income, 2009, pg. 29; Also Rev. Rul. 71-70, 1971-1 CB 27.

${ }^{9}$ IRS Publication 525, Taxable and Nontaxable Income, 2009, pg. 29; Also Rev. Rul. 57-383, 1957-2 CB 44.

${ }^{10}$ IRS Publication 525, Taxable and Nontaxable Income, 2009, pg. 29

${ }^{11}$ See Form W-4V and related instructions.

${ }^{12}$ Donohoe, Robert Matthew, TC Summary Opinion 2002-136.

${ }_{13}$ IRS Publication 525, Taxable and Nontaxable Income, 2009, pgs. 29-30.

${ }^{14}$ Sec. 102.

${ }^{15}$ Sec. 102(c)(1). 
${ }^{16}$ See IRS Publication 950, Introduction to Estate and Gift Taxes, December 2009.

${ }^{17}$ Secs. 1221 and 1222.

${ }^{18}$ Sec. 121(a) and (b). Also IRS Publication 523, Selling Your Home, 2008.

${ }^{19}$ See Sec. 165(c).

${ }^{20}$ Sec. 121(b)(3).

${ }^{21}$ Sec. 121(c)(2)(B) and Treas. Reg. Sec. 1.121-3(c).

${ }^{22}$ Treas. Reg. Sec. 1.121-3(e).

${ }^{23}$ Sec. 121(c)(1).

${ }^{24}$ Secs. 421 and $422(\mathrm{a})(1)$.

${ }^{25}$ Secs. 422(a)(2) and (c)(3).

${ }^{26}$ Sec. 401(a)(9); also IRS Publication 575, Pension and Annuity Income, 2009.

${ }^{27}$ Sec. 3405(c).

${ }^{28}$ See IRS Publication 590, Individual Retirement Arrangements (IRAs), 2009.

${ }^{29}$ Sec. $72 \mathrm{t}$.

${ }^{30}$ Rev. Rul. 85-121, 1985-2 CB 56.

${ }^{31}$ PLR 199612008 (December 18, 1995).

${ }^{32}$ Sec. 132(d); Treas. Reg. Sec. 1.132-5(a)(2)(i); Rev. Rul. 92-69, 1992-2 CB 51.

${ }^{33}$ Rev. Rul. 92-69, 1992-2 CB 51.

${ }^{34}$ Sec. 67(a) and (b)..

${ }^{35}$ Rev. Rul. 75-120, 1975-1 CB 55. See IRS Publication 529, Miscellaneous Deductions, 2009, pg. 5 for job search expenses. See IRS Publication 463, Travel, Entertainments, Gifts, and Car Expenses, 2008, for travel expenses.

${ }^{36}$ Sec. 67(a) and (b); Treas. Reg. Sec. 1.67-1T(a)(1)(i).

${ }^{37}$ Sec. 217(a)

${ }^{38}$ Sec. $217(\mathrm{~d})(1)$.

${ }^{39}$ Sec. $217(d)(2)$ and (3).

${ }^{40}$ Sec. 217(b).

${ }^{41}$ See Form 3903 and related instructions. Also IRS Publication 521, Moving Expenses, 2008.

${ }^{42}$ Sec. 32. Also IRS Publication 596, Earned Income Credit, 2009.

${ }^{43}$ Sec. 3507.

${ }^{44}$ See IRS Publication 970, Tax Benefits for Higher Education, 2008.

${ }^{45}$ Sec. 222

${ }^{46}$ Sec. $25 \mathrm{~A}$

${ }^{47}$ The American Recovery and Reinvestment Act of 2009 (P.L. 111-5) added new Code Section 25A(i).

${ }^{48} \mathrm{Sec} .25 \mathrm{~A}(\mathrm{c})$.

${ }^{49}$ Sec. 35. Also see IRS Fact Sheet 2003-15 (August 2003). Created by the Trade Act of 2002, P.L. 107-210 (August 6, 2002) and modified by the American Recovery and Reinvestment Act of 2009, P.L. 111-5 (February 17, 2009).

${ }^{50}$ See press release dated July 22, 2009 at Careerbuilders.com.

${ }^{51}$ Sec. 6017

${ }^{52}$ Also Schedule SE (Form 1040), Self-Employment Tax and related instructions. Secs. 1402(a)(12) and 164(f).

${ }^{53}$ Sec. 6654.

${ }^{54}$ See Form 1040-ES and related instructions.

${ }_{55}^{55}$ Sec. 6654(d).

${ }^{56} \mathrm{Sec} .6654(\mathrm{~d})$.

${ }_{58}^{57}$ See Form 9465, Installment Agreement Request, and related instructions.

${ }^{58}$ Sec. $7803(\mathrm{c})$.

${ }^{59}$ Sec. 7811(a)(2). 


\section{TAX CONSIDERATIONS FOR DISPLACED WORKERS EXECUTIVE SUMMARY - SIDEBAR}

\section{Income}

1. Severance pay or lump sum payments for cancellation of an employment contract are taxable income.

2. Golden Parachute payments are considered excess severance pay and are taxable income.

3. Unemployment benefits sponsored by a state or federal government are taxable after the first $\$ 2,400$ in 2009 .

4. Accrued vacation pay or sick leave paid on termination of an employee is taxable income.

5. Gifts from family or friends are not taxable income

6. Sale of assets that produce a gain is taxable income. If assets are held more than one year the gain may be taxable at a lower capital gains tax rate

7. Sale of Personal Residence may provide a gain that can be excluded from income. This gain exclusion is up to $\$ 250,000$ for a single taxpayer or $\$ 500,000$ for a married couple filing a joint return if the taxpayer meets the requirements for owning and using the principal residence for two of the last five years ending on the date of sale. Special exceptions to the ownerships and use test for taxpayer changes in employment or unforeseen circumstances.

8. Incentive Stock Options (ISO) typically do not create taxable income by holding or exercising them. Taxable income is typically recognized when the taxpayer sells the ISO stock. Holding periods on the ISO need to be met to avoid taxation.

9. Retirement Plan Withdrawals received by an employee before their eligible retirement age will be subject to income tax. Early withdrawals may be subject to an additional $10 \%$ tax for early distribution unless the taxpayer meets one of the few exceptions to the early withdrawal penalty.

10. Accident and Health Benefits for laid-off workers who receive continuing accident and health benefit coverage under a collective bargaining agreement or severance plan do not include that benefit in gross income.

\section{Deductions}

1. Job Placement Assistance may be excluded from income if it meets the two requirements of a working condition fringe benefit. If not excluded from income it may be deducted as a miscellaneous itemized deduction as employee business expense.

2. Job Hunting Expenses of a terminated employee may be deducted as a miscellaneous itemized deduction if the new job is in the same trade or business as their previous job.

3. Moving Expenses may be deducted before Adjusted Gross Income (AGI) if the taxpayer changes from being self-employed to an employee or from being an employee to self employed. In addition, if an unemployed taxpayer finds a job in a new area moving expenses can be deducted. The moving expense deduction requires a time and distance test be met.

\section{Tax Credits}

1. Earned Income Credit can provide some much needed cash for taxpayers who find themselves with much lower income. This refundable credit is available even if you have no tax liability.

2. Education Credits like the American Opportunity Tax Credit, Lifetime Learning Credit or the deduction before AGI for postsecondary education are available to taxpayers who meet the requirements while re-tooling for their next job.

3. Health Coverage Tax Credit (HCTC) is available to taxpayers who lost their jobs because of increased imports or shift in production to another country.

\section{Special Considerations}

1. Estimated Tax Payments for laid-off employees may be necessary to adjust to their new economic environment if they received large severance payment which did not have income tax withheld or if they plan to switch to a selfemployed status.

2. Installment Payments may be a good strategy for taxpayers who find that they have little cash to pay their income taxes when filing their return.

3. Taxpayer Advocate Service can help the taxpayer when the IRS does not seem to recognize or respond to a significant hardship of the taxpayer. 
NOTES 